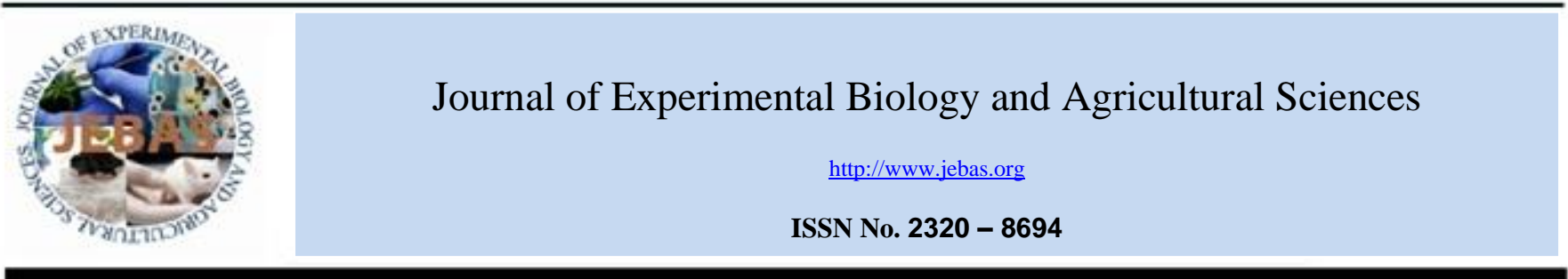

\title{
PROPHYLACTIC EFFECT OF CAMEL MILK ON PHYSIOLOGICAL AND BIOCHEMICAL CHANGES IN $\mathrm{CCL}_{4}$-INTOXICATED RATS
}

\author{
Zahran $\mathrm{F}^{1}$, Gabr $\mathrm{SA}^{2, *}$, Abd El-Moneim $\mathrm{AE}^{2}$, Sharoud $\mathrm{MN}^{2}$, Hassanin $\mathrm{WF}^{2}$, Mesalam $\mathrm{NM}^{2}$ \\ ${ }^{1}$ Biochemistry Department, Faculty of Science, Zagazig University, Egypt \\ ${ }^{2}$ Biological Applications Department, Nuclear Research Centre, Atomic Energy Authority, Egypt \\ Received - September 18, 2017; Revision - November 03, 2017; Accepted - February 05, 2018 \\ Available Online - February 20, 2018
}

DOI: http://dx.doi.org/10.18006/2018.6(1).211.219

\section{KEYWORDS}

Prophylactic effects

Camel milk

$\mathrm{CCl}_{4}$

Silymarin

Oxidative stress

Rats

\section{ABSTRACT}

Present study has been carried out evaluate prophylactic effect of Camel milk on physiological and biochemical changes in CCl4-intoxicated rats. A total of 36 male albino rats were randomly divided into 6 groups viz. control group (G1), silymarin (SM) group (G2), camel milk (CM) group (G3), $\mathrm{CCl}_{4}$ intoxicated group (G4), silymarin prophylactic group (G5) and camel milk prophylactic group (G6). Each group has six rats. After completion of the study ( $8 \mathrm{wks})$, blood samples were collected and hematological parameters, liver contents of glutathione (GSH), malondialdhyde (MDA), superoxide dismutaseactivity (SOD), serum urea, uric acid, creatinine, testosterone, estradiol were measured. The results of this study revealed that $\mathrm{CCl}_{4}$ toxicity significantly reduced $\mathrm{Hb}$ level, RBCs count and PCV, whereas it significantly increased the WBCs count with respect to normal control. Intoxication of $\mathrm{CCl}_{4}$ in G4 rats led to microcytic hypochromic anaemia, increased erythrocyte fragility and, leukocytosis was accompanied neutrophils increases and a decrease in lymphocyte counts. Also, $\mathrm{CCl}_{4}$ produced significant increase in serum urea, uric acid, creatinine and estradiol level and decrease in circulating testosterone level compared with normal rats. Pre-treatment with CM and SM brought significant restoration in hematological, renal function parameters and sexual hormones disturbance. Moreover, lipid peroxidation and oxidative stress were obviously noted in $\mathrm{CCl}_{4}$ intoxicated (G4) organism where a
* Corresponding author

Current Address: Khurma University Collage, Taif University, Kingdom of Saudi Arabia E-mail: drsalahgabr@yahoo.com (Gabr SA)

Peer review under responsibility of Journal of Experimental Biology and Agricultural Sciences.

Production and Hosting by Horizon Publisher India [HPI] (http://www.horizonpublisherindia.in/).

All rights reserved.
All the article published by Journal of Experimental Biology and Agricultural Sciences is licensed under a Creative Commons Attribution-NonCommercial 4.0 International License Based on a work at www.jebas.org.

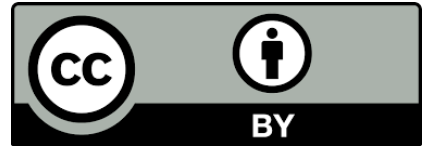


significant increase in liver MDA and decrease in its content of GSH and SOD activity. Contrarily, pre-treatment with CM and SM did not only decrease liver content of MDA but also increased hepatic GSH and SOD activity, suggesting that $\mathrm{CM}$ and $\mathrm{SM}$ attenuated $\mathrm{CCl}_{4}$-induced oxidative stress. In conclusion, CM and SM had a considerable prophylactic effectiveness against hematotoxicity, oxidative stress, lipid peroxidation, renal impairment and sexual hormones disturbances developed by intraperitoneal injection of rats withCCl${ }_{4}$.

\section{Introduction}

Liver is the largest body organ and plays a vital role in detoxification of deleterious materials. It regulates numerous metabolic functions and maintains body homeostasis (Mayuren et al., 2010). Liver disorders are one of the most common problems throughout the world. Liver injury can be induced by certain xenobiotics and microbialin filtration via ingestion or infection (Hai et al., 2011). Carbon tetrachloride $\left(\mathrm{CCl}_{4}\right)$ is well-known as xenobiotic agent. Liver is not the only the target organ of CCl4 but it also affects several body organs such as lungs, heart, testes, kidneys and brain (Ozturk et al., 2003). Evidence demonstrated that $\mathrm{CCl}_{4}$ activated highly reactive trichloromethyl radical in liver which initiates free radical mediated lipid peroxidation of cell membrane phospholipids (rich with polyunsaturated fatty acids) which are vulnerable to peroxidation. Accordingly, various functional and morphological changes are developed in liver cell membrane which caused an accumulation of lipid-derived oxidants and finally liver injury encountered (Singh et al., 2008). $\mathrm{CCl}_{4}$ is rapidly absorbed by liver tissue in humans and animals. Once it absorbed, it is widely spread among tissues, especially those with high lipid content, reaching peak concentrations in $<1-$ 6 hours, depending on exposure dose or its duration time (U.S. EPA. IRIS, 2010).

Oxidative stress and membrane damage in hepatocytes, mainly caused via CYP2E1 (Manibusan et al., 2007). Also, $\mathrm{CCl}_{4}$ alter the antioxidant profile of the liver by reacting with sulfhydryl groups of glutathione (GSH) and thiols group of protein, including the antioxidant enzymes as superoxide dismutase (SOD), catalase (CAT), glutathione peroxidase (GPx), glutathione reductase (GR), and glutathione transferase (GST) (Knockaert et al., 2012; Yang et al., 2015).

Camel milk (CM) is an excellent source of well-balanced nutrients. It exhibits a range of biological activities that influence digestion, metabolism, growth and development of specific organs. These biological properties are mainly due to the presence of certain peptides and proteins in milk (Yagil et al., 1984; Korhonen \& Pihlanto, 2001). Camel milk is different from other ruminant milk; it has low cholesterol, sugar and protein but high minerals such as sodium, potassium, iron, copper, zinc and magnesium. Besides this, presence of vitamins A, B2, C and E was also reported in camel milk. The presence of high insulin concentration was also reported in camel milk (Knoess, 1979). Along with this it can be consumed by lactase-deficient individuals because of non-allergic properties of camel milk. A series of metabolic and autoimmune diseases can be successfully cured by camel's milk. In India, camel's milk widely used therapeutically against dropsy, jaundice, problems of the spleen, tuberculosis, asthma, anemia, piles and diabetes (Rao et al., 1970). Further, antibacterial and antiviral activities of $\mathrm{CM}$ were also studied by El-Agamy et al., (1992).

Silymarin (SM), a polyphenolic flavonoid confined from milk and this is another antioxidant that has been found affective against liver injuries induced by various hepatotoxins including $\mathrm{CCl}_{4}$ (Shaker et al., 2011; Bektur et al., 2016). SM also prevents lipoperoxidation of membranes and scavenges ROS, thus increases GSH availability (Parveen et al., 2011; Vargas-Mendoza et al., 2014). The aim of this study was to investigate the prophylactic effect of camel milk and silymarin on hemotoxicity, oxidative stress, lipid peroxidation, renal function and sex hormone disturbances in $\mathrm{CCl}_{4}$-intoxicated rats.

\section{MATERIALS AND METHODS}

\subsection{Chemicals}

Carbontetrachloride $\left(\mathrm{CCl}_{4}\right)$ obtained from LobaChemie, India. Solution of $\mathrm{CCl}_{4}$ prepared by dissolving in $50 \%$ olive oil $\mathrm{V}: \mathrm{V}$ and injected intraperitoneally in to the experimental rats at a dose of 1 $\mathrm{ml} / \mathrm{kgb} . \mathrm{w}$, once daily, 3 times weekly for four weeks to induce toxicity as described by Abdel-Moneim et al. (2015).

Raw silymarin was obtained from ElobourMedern Pharmaceutical Industries Co., Egypt. Rats were given silymarinorally at a dose of $150 \mathrm{mg} / \mathrm{kgb} . \mathrm{w}$ suspended in distilled water (Chen et al., 2012). Recommended dose of silymarin were given once daily, 5 times in a week for 2 weeks and 3 times in a week for next 4 weeks.

Early morning, hand milking camel milk (CM) was collected daily from western desert camel farm in sterile screw capped 
containers and transported to the laboratory in cool boxes. CM was given to rats in a dose of $5 \mathrm{ml} /$ rat according to El Miniawy et al. (2014), once daily, 5 times in a week for 2 weeks and 3 times in a week for next 4 weeks.

\subsection{Experimental animals}

Total thirty six (36) adult male albino rats weighing about $180 \mathrm{~g}$ in average were used for this study. They were selected among the animals bred in the small Animal House of the Nuclear Research Center, Atomic Energy Authority, Egypt. The animals were acclimatized for two weeks under ambient environmental conditions and housed in well aerated cages.

\subsection{Animal grouping and treatment}

Animals were randomly assigned into six equal groups viz. Normal control animals, without any treatment (G1), SM ingested (G2), CM drenched (G3), $\mathrm{CCl}_{4}$ intoxicated (G4), SM prophylactic group (G5 - SM treatment for first six weeks $+\mathrm{CCl}_{4}$ treatment started from fifth week of SM treatment and continue for the next 4 weeks) and $\mathrm{CM}$ prophylactic group (CM treatment for first six weeks $+\mathrm{CCl}_{4}$ treatment started from fifth week of $\mathrm{CM}$ treatment and continue for the next 4 weeks) and they were fed on a balanced rodent diet. They had free access to feed and drinking water from the beginning of the experiment until its termination

At the end of each treatment and after overnight fasting, animals were decapitated and trunk blood samples were collected in tubes with or without anticoagulant for assaying hematological indices, serum levels of renal function tests and sex hormones. Simultaneously liver was excised from each scarified rat. Promptly liver samples were rinsed in $0.1 \mathrm{M}$ cold phosphate buffer (PH 7.4) and homogenized using a Teflon pestle to prepare $10 \%$ homogenates used for assessment of oxidative stress and peroxidation biomarkers.

\subsection{Hematological Measurements}

Blood samples were collected in EDTA coated tubes and used for determination of hematological parameters included hemoglobin (Hb) level, erythrocytes (RBCs), platelets (PLT) and leucocytes (WBCs) counts which were evaluated according to Dacie \& Lewis (1993). Mean corpuscular volume (MCV), mean corpuscular hemoglobin (MCH) and mean corpuscular hemoglobin concentration (MCHC) were calculated from the values of PCV, Hb and RBCs count as described by Jain (1986). For differential leucocyte counts, blood smear were stained with Giemsa.

\subsection{TBARS and antioxidant enzymes assays}

Lipid peroxidation biomarkers were expressed as malondialdhyde (MDA) and determined according to Satoh (1978). Reduced glutathione (GSH) was assayed as described by Beutler et al. (1963) and superoxide dismutase was measured by the procedure given by Nishikimi et al. (1972).

\subsection{Levels of serum testosterone and estradiol estimation}

Levels of serum testosterone and estradiol were assayed by RIA kits (10227-Czch Republic purchased from IMMUNOTECH Company) by following manufacturer's instructions.

\subsection{Renal function tests}

Renal function tests were determined by following the method of Fawcett \& Scott, (1960) for urea, Barham \&Trinder, (1972) for uric acid and Larsen, (1972) for creatinine.

\subsection{Statistical Analysis:}

The obtained results were expressed as means \pm standard errors. The data were subjected to $F$ test one way analysis of variance (ANOVA) according to Snedecor \& Cochran (1982) followed by Duncan's multiple range test (Duncan, 1955) to determine the significance of difference $(\mathrm{P} \leq 0.01)$ between means of treated groups.

\section{RESULTS}

Result of study presented in table 1, revealed that administration of $\mathrm{CCl}_{4}$ had negative effect on all studied hematological parameters. Significant reduction $(\mathrm{P}<0.01)$ was reported in $\mathrm{Hb}$ level, RBCs numbers, PCV, MCHC, PLT and lymphocyte counts. While, an improvement $(\mathrm{P}<0.01)$ was reported in $\mathrm{MCV}, \mathrm{MCH}$, WBCs and neutrophil counts in CM, SM treated animals as compared the control group. Similarly, when CM and SM were used as prophylactic agents against $\mathrm{CCl} 4$ toxicity, they nearly succeeded to bring back the values of the above mentioned parameters toward the basal figures of normal control groups.

Regarding to lipid peroxidation and oxidative stress, data presented in table 2 denoted that IP injection of rats with $\mathrm{CCl}_{4}$ (G4) led to a significant increase $(\mathrm{P}<0.01)$ in MDA content of liver. While, concentration of GSH and SOD activity were significantly $(\mathrm{P}<0.01)$ reduced as compared with their corresponding values in control group. Pre- treatments of $\mathrm{CM}$ and SM remarkably repaired the negative effects of $\mathrm{CCl}_{4}$ on hepatic MDA and GSH whereas the activity of SOD was completely restored and the level of GSH was partially returned close to the normal values of control group. 
Table 1 Effect of camel milk and silymarin on hematological parameters of normal $\mathrm{CCl}_{4}$ intoxicated rats

\begin{tabular}{|c|c|c|c|c|c|c|c|c|c|c|}
\hline \multirow[b]{2}{*}{ Group } & \multicolumn{10}{|c|}{ Hematological parameters } \\
\hline & $\begin{array}{l}\mathrm{Hb} \\
(\mathrm{g} / \mathrm{dl})\end{array}$ & $\begin{array}{l}\text { RBCs } \\
\left(10^{6} / \mathrm{mm}^{3}\right)\end{array}$ & PCV \% & $\begin{array}{r}\text { MCV } \\
\text { (fl) }\end{array}$ & $\begin{array}{r}\text { MCH } \\
(\mathbf{P g})\end{array}$ & $\begin{array}{r}\text { MCHC } \\
(\mathrm{g} / \mathrm{dl})\end{array}$ & $\begin{array}{c}\text { PLT } \\
\left(10^{3} / \mathrm{mm}^{3}\right)\end{array}$ & $\begin{array}{l}\text { WBCs } \\
\left(10^{3} / \mathrm{mm}^{3}\right)\end{array}$ & $\begin{array}{c}\text { Neutrophils } \\
(\%)\end{array}$ & $\begin{array}{c}\text { Lymphocytes } \\
(\%)\end{array}$ \\
\hline G1 & $13.70^{\mathrm{b}} \pm 0.03$ & $6.86^{\mathrm{b}} \pm 0.09$ & $41.10^{\mathrm{cd}} \pm 0.22$ & $260.01^{\mathrm{bc}} \pm 1.04$ & $19.98^{\mathrm{b}} \pm 0.28$ & $33.32^{\mathrm{a}} \pm 0.12$ & $467.2^{\mathrm{bc}} \pm 33.6$ & $11.82^{\mathrm{b}} \pm 0.40$ & $24.17^{\mathrm{bc}} \pm 0.60$ & $67.0^{\mathrm{ab}} \pm 0.73$ \\
\hline G2 & $14.25^{\mathrm{a}} \pm 0.14$ & $7.07^{\mathrm{ab}} \pm 0.14$ & $44.0^{\mathrm{b}} \pm 0.40$ & $62.68^{\mathrm{b}} \pm 0.88$ & $20.28^{\mathrm{b}} \pm 0.27$ & $32.45^{\mathrm{b}} \pm 0.14$ & $386.2^{\mathrm{cd}} \pm 55.7$ & $10.88^{\mathrm{b}} \pm 1.84$ & $19.33^{\mathrm{c}} \pm 0.56$ & $64.2^{\mathrm{bc}} \pm 0.60$ \\
\hline G3 & $13.82^{\mathrm{b}} \pm 0.15$ & $7.39^{\mathrm{a}} \pm 0.08$ & $45.6^{\mathrm{a}} \pm 0.54$ & $61.82^{\mathrm{b}} \pm 0.23$ & $18.75^{\mathrm{c}} \pm 0.07$ & $30.37^{\mathrm{d}} \pm 0.14$ & $485.5^{\mathrm{abc}} \pm 29.7$ & $12.32^{\mathrm{b}} \pm 0.53$ & $21.83^{\mathrm{bc}} \pm 0.83$ & $71.2^{\mathrm{a}} \pm 1.64$ \\
\hline G4 & $10.29^{\mathrm{e}} \pm 0.19$ & $4.23^{\mathrm{c}} \pm 0.14$ & $35.47^{\mathrm{e}} \pm 0.27$ & $84.37^{\mathrm{a}} \pm 2.90$ & $24.40^{\mathrm{a}} \pm 0.59$ & $29.00^{\mathrm{e}} \pm 0.50$ & $330.1^{\mathrm{d}} \pm 27.8$ & $20.61^{\mathrm{a}} \pm 0.63$ & $31.00^{\mathrm{a}} \pm 2.44$ & $58.60^{\mathrm{c}} \pm 2.70$ \\
\hline G5 & $13.12^{c} \pm 0.06$ & $7.20^{\mathrm{ab}} \pm 0.13$ & $42.02^{c} \pm 0.22$ & $58.33^{\mathrm{bc}} \pm 1.13$ & $18.38^{\mathrm{c}} \pm 0.42$ & $31.23^{\mathrm{c}} \pm 0.11$ & $599.3^{\mathrm{a}} \pm 31.4$ & $12.53^{\mathrm{b}} \pm 1.19$ & $22.33^{\mathrm{bc}} \pm 1.28$ & $61.8^{\mathrm{bc}} \pm 0.87$ \\
\hline G6 & $12.70^{\mathrm{d}} \pm 0.17$ & $7.07^{\mathrm{ab}} \pm 0.06$ & $40.40^{\mathrm{d}} \pm 0.44$ & $57.25^{\mathrm{c}} \pm 0.36$ & $18.03^{\mathrm{c}} \pm 0.25$ & $31.43^{\mathrm{c}} \pm 0.30$ & $517.8^{\mathrm{ab}} \pm 54.4$ & $13.35^{\mathrm{b}} \pm 0.97$ & $26.33^{\mathrm{ab}} \pm 2.81$ & $61.3^{\mathrm{bc}} \pm 3.17$ \\
\hline
\end{tabular}

Data are expressed as Mean \pm S.E, Mean values with different letters in the same column are significantly different at $(\mathrm{P}<0.01)$

Table 2 Effect of camel milk and silymarin treatment on hepatic lipid peroxides markers as (MDA), reduced glutathione (GSH) and superoxide dismutase (SOD) of normal rats and $\mathrm{CCl}_{4}$ intoxicated rats

\begin{tabular}{|cccc|} 
Group & \multicolumn{3}{c|}{ Liver Functioning Parameters } \\
& $\begin{array}{c}\text { MDA } \\
(\text { nmol/g.tissue })\end{array}$ & $\begin{array}{c}\text { GSH } \\
(\mathrm{mg} / \mathrm{g} . \text { issue })\end{array}$ & $\begin{array}{c}\text { SOD } \\
(\mathrm{U} / \mathrm{g} \text {. tissue })\end{array}$ \\
\hline G1 & $11.89^{\mathrm{b}} \pm 0.36$ & $61.99^{\mathrm{a}} \pm 0.56$ & $12561.5^{\mathrm{a}} \pm 367.7$ \\
\hline $\mathrm{G} 2$ & $8.04^{\mathrm{bc}} \pm 0.94$ & $58.40^{\mathrm{a}} \pm 1.38$ & $12357.9^{\mathrm{a}} \pm 190.5$ \\
\hline G3 & $6.69^{\mathrm{c}} \pm 1.40$ & $59.20^{\mathrm{a}} \pm 2.12$ & $11735.2^{\mathrm{ab}} \pm 263.0$ \\
\hline G4 & $20.38^{\mathrm{a}} \pm 2.19$ & $22.87^{\mathrm{c}} \pm 0.77$ & $10517.9^{\mathrm{c}} \pm 364.4$ \\
\hline G5 & $22.31^{\mathrm{a}} \pm 1.62$ & $40.08^{\mathrm{b}} \pm 1.23$ & $10864.5^{\mathrm{bc}} \pm 443.8$ \\
\hline G6 & $19.75^{\mathrm{a}} \pm 1.49$ & $38.60^{\mathrm{b}} \pm 1.38$ & $11517.5^{\mathrm{abc}} \pm 179.5$ \\
\hline
\end{tabular}

Data are expressed as Mean \pm S.E, Mean values with different letters in the same column are significantly different at $\mathrm{P}<0.01$

Table 3 Effect of camel milk and silymarin treatment on serum urea, uric acid and creatinine of normal and $\mathrm{CCl}_{4}$ intoxicated rats

\begin{tabular}{cccc|}
\hline Group & $\begin{array}{c}\text { Urea } \\
(\mathrm{mg} / \mathrm{dl})\end{array}$ & $\begin{array}{c}\text { Uric acid } \\
(\mathrm{mg} / \mathrm{dl})\end{array}$ & $\begin{array}{c}\text { Creatinine } \\
(\mathrm{mg} / \mathrm{dl})\end{array}$ \\
\hline G1 & $41.64^{\mathrm{c}} \pm 1.60$ & $3.13^{\mathrm{a}} \pm 0.11$ & $1.07^{\mathrm{bcd}} \pm 0.05$ \\
\hline G2 & $49.92^{\mathrm{b}} \pm 1.81$ & $2.38^{\mathrm{b}} \pm 0.15$ & $0.96^{\mathrm{cd}} \pm 0.05$ \\
\hline G3 & $48.92^{\mathrm{b}} \pm 1.10$ & $2.18^{\mathrm{b}} \pm 0.06$ & $0.92^{\mathrm{d}} \pm 0.09$ \\
\hline G4 & $56.76^{\mathrm{a}} \pm 1.65$ & $3.56^{\mathrm{a}} \pm 0.25$ & $1.47^{\mathrm{a}} \pm 0.06$ \\
\hline G5 & $48.03^{\mathrm{b}} \pm 1.15$ & $3.00^{\mathrm{a}} \pm 0.23$ & $1.14^{\mathrm{bc}} \pm 0.07$ \\
\hline G6 & $48.00^{\mathrm{b}} \pm 2.31$ & $3.20^{\mathrm{a}} \pm 0.32$ & $1.23^{\mathrm{b}} \pm 0.06$ \\
\hline
\end{tabular}

Data are expressed as Mean \pm S.E, Mean values with different letters in the same column are significantly different at $\mathrm{P}<0.01$
Table 3 visualized that $\mathrm{CCl}_{4}$ intoxication induced obvious renal impairment as the levels of serum urea and creatinine were significantly $(\mathrm{P}<0.01)$ higher. While, insignificant increase of uric acid was observed in G3 as compared to control group. Clearly, the prophylactic effects of $\mathrm{CM}$ and silymarin was evident when they were given to $\mathrm{CCl}_{4}$ intoxicated rats. This allegation is confirmed by significant $(\mathrm{P}<0.01)$ decrease noted in the level of urea, uric acid and creatinine in pre $\mathrm{CM}$ and $\mathrm{SM}$ treated groups as compared with those injected with $\mathrm{CCl}_{4}$.

The data cited in table 4 revealed that administration of $\mathrm{CCl}_{4}$ to male albino rats led to disturbances in the levels of serum sex hormones. Where testosterone was significantly $(\mathrm{P}<0.01)$ decreased and estradiol was significantly $(\mathrm{P}<0.01)$ increased in comparison to normal control group. Alternations of these hormones were significantly $(\mathrm{P}<0.01)$ reversed by pre administration of $\mathrm{CM}$ and $\mathrm{SM}$ to $\mathrm{CCl}_{4}$ intoxicated rats. Unsurprisingly, the results of this investigation revealed that administration of $\mathrm{CM}$ alone to normal male rats led to significant $(\mathrm{P}<0.01)$ increment of estradiol level.

\section{Discussion}

In the present study, reduction was noted in the levels of blood $\mathrm{Hb}$, RBCs count and $\mathrm{PCV}$ in $\mathrm{CCl}_{4}$ intoxicated rats than healthy control, CM and SM group may attributed to the cytotoxic effect and suppression of the erythropoiesis caused by $\mathrm{CCl}_{4}$. Similar results were reported by Mandal et al. (1998). In this study, negative alternations was reported in $\mathrm{Hb}, \mathrm{RBCs}, \mathrm{PCV}, \mathrm{MCV}$, $\mathrm{MCH}$ and $\mathrm{MCHC}$ in $\mathrm{CCl}_{4}$ group which indicated that $\mathrm{CCl}_{4}$ intoxication caused microcytic hypochromic anemia. Tung et al. (1975) referred these effects to disturbed hematopoiesis, destruction of erythrocytes and reduction in the rate of their formation and/or their enhanced removal from circulation. Moreover, Makni et al. (2012) added that peroxidation developed

Journal of Experimental Biology and Agriculture Science http://www.jebas.org 
Table 4 Effect of camel milk and silymarin treatment on serum testosterone and estradiol levels of normal and $\mathrm{CCl}_{4}$ intoxicated rats

\begin{tabular}{|ccc|}
\hline Group & $\begin{array}{c}\text { Testosterone } \\
(\mathrm{ng} / \mathrm{ml})\end{array}$ & $\begin{array}{c}\text { Estradiol } \\
(\mathrm{pg} / \mathrm{ml})\end{array}$ \\
\hline $\mathrm{G} 1$ & $6.30^{\mathrm{b}} \pm 0.31$ & $67.25^{\mathrm{c}} \pm 2.62$ \\
\hline $\mathrm{G} 2$ & $3.52^{\mathrm{c}} \pm 0.18$ & $85.51^{\mathrm{c}} \pm 2.37$ \\
\hline $\mathrm{G} 3$ & $7.34^{\mathrm{a}} \pm 0.23$ & $105.56^{\mathrm{b}} \pm 0.72$ \\
\hline $\mathrm{G} 4$ & $0.52^{\mathrm{f}} \pm 0.08$ & $134.36^{\mathrm{a}} \pm 12.11$ \\
\hline $\mathrm{G} 5$ & $1.55^{\mathrm{e}} \pm 0.15$ & $72.63^{\mathrm{c}} \pm 2.23$ \\
\hline $\mathrm{G} 6$ & $2.51^{\mathrm{d}} \pm 0.24$ & $83.39^{\mathrm{c}} \pm 2.22$ \\
\hline
\end{tabular}

Data are expressed as Mean \pm S.E, Mean values with different letters in the same column are significantly different at $\mathrm{P}<0.01$

by $\mathrm{CCl}_{4}$ led to a destruction of membrane protein, alternation of membrane bound enzymes as well as erythrocyte osmotic fragility. The significant increase in WBCs noticed herein $\mathrm{CCl}_{4}$ group which may be due to the release of marginal neutrophils and other neutrophil pool into the circulation which produced the observed neutrophilia in those rats which were under the influence of stress hormones and catecholamine (Swenson, 1993).

Results of this study revealed that CM ingestion can mitigate all the adverse effects of $\mathrm{CCl}_{4}$ on hematological parameters by the virtue of its high content of vit $\mathrm{E}$ which play a major role in maintaining the flexability of RBCs and reduce the fragility and damage as a result of the oxidation of membrane phospholipids of RBCs (Kraus et al., 1997). This vitamin also has a direct impact on the formation of RBCs in the bone marrow (McDowell, 2000). Likewise CM, SM possesses hematopoietic activity since it is nothematotoxic. According to Kumarappan et al. (2010) camel milk also has antioxidative properties. Therefore, when $\mathrm{CM}$ or $\mathrm{SM}$ was used as prophylactic agents in combination with $\mathrm{CCl}_{4}$, they can almost reverse negative features of hemtoxicity.

GSH is the major thiol in mammalian cells which prevents interaction of ROS with critical cellular constituents. It is the master non enzymetic antioxidant that can directly conjugate with free radical and its status may consider a good measure of antioxidant. MDA is the major oxidative degeneration product of membrane unsaturated fatty acids which is the end product of lipid peroxidation.

In the present study, administration of $\mathrm{CCl}_{4}$ was accompanied by increased lipid peroxidation, reduced SOD activity and depletion in GSH in liver. Treatment with SM protects liver from GSH depletors such as paracetamol (Videla \& valenzela, 1982). Increased lipid peroxidation is evidenced in this study by the elevated level of MDA in hepatic tissue of $\mathrm{CCl}_{4}$ treated rats.
These results are in agreement with the findings of Kim et al. (2003). The decreased level of MDA, increased content of GSH and elevated activity of SOD in $\mathrm{CCl}_{4}$ intoxicated group after giving $\mathrm{CM}$ indicated that lipid peroxidation was inhibited. This action could be attributed to the high content of $\mathrm{CM}$ with vitamins C, A, E, zinc and magnesium. All these constituents are potent antioxidants can protect liver cells from injury (Barbagallo et al., 1999; Althnaian, 2012). In accordance with the results of the current study, Ibrahim et al. (2017) showed that CM has hepatoprotective action against acetominophenon induced hepatotoxicity in mice, possibly in part through antioxidative effects. El Miniawy et al. (2017) ascribed this positive effect of $\mathrm{CM}$ to the improvement observed in SOD activity and reduction of the lipid peroxidation. The effect of CM similar to the effect of $\mathrm{SM}$ in comparison with $\mathrm{CCl}_{4}$-intoxicated rats.

Kidney function tests include blood urea, uric acid and serum creatinine. Among these, serum creatinine is a useful indicator of regular filtration in kidney. It is the end product of creatine metabolism in muscle. Urea and uric acid are the principal waste products of protein catabolism. They are synthesized in the liver from the ammonia which produced as a result of amino acids deamination (Young et al., 1972). In the kidney, creatinine is distilled by the glomerulus and excreted by the tubules and only free creatinine appears in the blood serum (Baker et al., 1979).

In the present study, the increased levels of serum urea, creatinine was reported in $\mathrm{CCl}_{4}$ treated group and this was significantly higher than the control one which reflected the impairment in renal functions alongside with oxidative stress in kidney. These results are in accordance with findings of Churchill et al. (1983), Perez et al. (1987), Khan et al. (2009) and Hamed et al. (2012). It is believed that CCL treatment causes glomerular hypercellularity, moderate to severe necrosis and tubule interstitial alterations which cause alteration in the capacity for tubular absorption thus bringing about functional overload of nephrons with subsequent renal dysfunction (Adewole et al., 2007).

High levels of urea and creatinine indicates sever disturbances in kidney functioning (Maxine \& Benjamin, 1985). Supplementation of $\mathrm{CCl}_{4}$ injected rabbits with $\mathrm{CM}$ significantly reduced the rise in serum creatinine levels, compared to $\mathrm{CCl} 4$-induced rabbits by enhancing the renal function that is generally impaired in CCl4induced rabbits (Omar \& Hmmam, 2014). Further, Venkatanarayana et al. (2012) and Yacout et al. (2012) showed that administration of $\mathrm{CC} 14$ causes nephrotoxicity which significantly elevated level of urea and creatinine inside the serum which attributed the damage of nephron structural integrity (Khan et al., 2012). The increased creatinine level suggests that muscular wasting occurred during $\mathrm{CCl}_{4}$ intoxication since creatinine production has a direct relationship with muscle mass (Banfi\& Del Fabbro, 2006). 
The presence of vit $\mathrm{C}$ can significantly minimize blood urea nitrogen (BUN) level in diabetic rats (Al-Shamsi et al., 2006). CM have to three times higher vit $\mathrm{C}$ level than dairy milk (Farah et al., 1992). Hence it is postulated that the higher content of vit $C$ in $\mathrm{CM}$ may act as scavenger of free radicals developed as a result of $\mathrm{CCl}_{4}$ toxicity (Cecen et al., 2010).

Present study revealed that when SM or CM were ingested together with $\mathrm{CCl}_{4}$, kidney function tests were significantly improved as compared to $\mathrm{CCl}_{4}$ group. It is well known that gonadal activity relies on normal liver function. However, specific clinical signs of hypogonadism are commonly encountered in patients suffering from liver cirrhosis (Youssef \& Mullen, 2002; Zietz et al., 2003). It is well established that liver plays an essential role in synthesis of all compounds sharing in the maintenance of anadaquate endocrine homostasis such as hormones, their transport proteins and conversion enzymes (Youssef \& Mullen, 2002). Serum testosterone (the male sex hormones), FSH and LH were considerably decreased; While, estradiol and prolactin concentrations were remarkably raised in $\mathrm{CCl}_{4}$ intoxicated rats (Sahreen et al., 2013). In this manner, results of present study are concord with the findings of Youssef \& Mullen (2002) and Sahreen et al. (2013). The reduction in serum testosterone indicates either a direct effect of $\mathrm{CCl}_{4}$ on the number of leyding cells or as indirect impact by disturbing the hormonal environment at hypothalamopitutary axis (Latif et al., 2008). The enhancement of serum estradiol noted herein in $\mathrm{CCl}_{4}$ intoxicated group over control one could be ascribed to the conversion of androgens to estrogens under the effect of aromatase enzyme and deactivation of sex hormones by specific enzymes in $\mathrm{CCl}_{4}$ intoxicated liver. Thus, increased serum estradiol may be liable for the origin of hypogonadism observed in the current study. This result are in agreement with those obtained by Abdel-Rahman \& El-Nahary (2004) and Abdel Kader (2017) those who recorded a reduction in testosterone hormones after i.p. injection of CCl4 (1 $\mathrm{mg} / \mathrm{kg}$ b. wt.). Administration of $\mathrm{CM}$ to $\mathrm{CCl}_{4}$ intoxicated rats resulted in increased level of testosterone hormone significantly compared to $\mathrm{CCl}_{4}$ intoxicated rats. Soliman et al. (2016) showed that $\mathrm{CM}$ has an effective therapeutic role in improvement the altered gene expression luteinizing hormone receptor (LHR) using the semi-quantitative polymerase chain reaction (RT-PCR) in diabetic rats. LH acted on testicular leydig cell and stimulated the synthesis of testosterone, so the plasma level of testosterone is increased. The level of testosterone was significantly increased in $\mathrm{CM}$ group than $\mathrm{SM}$ group in $\mathrm{CCl}_{4}$-intoxicated rats. Meanwhile, no difference in the levels of estradiol between CM and SM groups in comparison to $\mathrm{CCl}_{4}$ group.

In this investigation, treatment of rats with $\mathrm{CCl}_{4}$ in combination with $\mathrm{CM}$ ameliorated the level of testosterone but this rise was not great enough and significantly different from $\mathrm{CCl}_{4}$. This improvement may be attributed to the high content of $\mathrm{CM}$ with vit $\mathrm{C}$ which scavenge superoxide, $\mathrm{H}_{2} \mathrm{O}_{2}$ and hydroxyl radicals, hence prevents lipid peroxidation (Curney et al., 1996; Veldink et al., 2007). CM is rich in zinc and magnesium which helps in absorption and metabolism of other powerful antioxidants such as vit E and C (Yousef et al., 2006).

References

Abdel Kader SM (2017) Effect of Salvia aegyptiaca Aqueous Extract on Some Neurohormonal Disorders Induced by Carbon Tetrachloride in Adult Male Albino Rats. Arab Journal of Nuclear Sciences and Applications 50: 205-216.

Abdel- Rahman M, El-Nahary H (2004) Therapeutic and protective role of panaxgensing extract on some neurotransmitters in rats treated with CCl4. Bullettin Pure and Applied. Science 23: 71-86.

Abdel-Moneim AM, Al-Kahtani MA, El-Kersh MA, Al-Omair MA (2015) Free Radical-Scavenging, Anti-Inflammatory / AntiFibrotic and Hepatoprotective Actions of Taurine and Silymarin against CCl4 Induced Rat Liver Damage. PLoS ONE 10(: e0144509). DOI: https://doi.org/10.1371/journal.pone.0144509.

Adewole SO, Salako AA, Doherty OW, Naicker T ( 2007) Effect of melatonin on carbon tetrachloride-induced kidney injury in Wistar rats . BMC Public Health 10: 153-64.

Al-Shamsi M, Amin A, Adeghate E (2006) Effect vof vitamin c on liver and kidney functions in normal and diabetic rats. Annals of the New York academic of Sciences $10: 371-390$.

Althnaian T (2012) Protective Effect of Camel Milk Against Carbon Tetrachloride Hepatotoxicity in Rats. Global Veterinaria 9 : 564-570.

Baker HJ, Lindsey JR, Weisbroth SH (1979) Housing to control research variables. In: the laboratory rats. Biological and Diseases, Academic Press, New York.

Banfi G, Del Fabbro M (2006) Relation between serum creatinine and body mass index in elite athletes of different sport disciplines. British Journal of Sports Medicine 40:675-8.

Barbagallo M, Dominguez LJ, Tagliamonte MR, Resnick LM, Paolisso G (1999) Effects of Vitamin E and Glutathione on Glucose Metabolism Role of Magnesium. Hypertension 34:1002-6.

Barham D, Trinder P (1972) An improved colour reagent for the determination of blood glucose by the oxidase system. Analyst 97 : $142-145$. 
Bektur NE, Sahin E, Baycu C, Unver G (2016) Protective effects of silymarin against acetaminohpen-induced hepatotoxicity and nephrotoxicity in mice. Toxicology and Industrial Health 32:589600 .

Beutler E, Duron O, Kellin BM (1963) Improved method for the determination of blood glutathione.Journal of Laboratory and Clinical Medicine 61: 882-888.

Cecen E, Dost T, Culhaci N, Karul A, Ergur B, Birincioglu M (2010) Protective effects of silymarin against doxorubicin-induced toxicity. Asian Pacific Journal of Cancer Prevention 12 : 2697704.

Chen IS, Chen YC, Chou CH, Chuang RF, Sheen LY, Chirinu CH (2012) Hepatoprotection of silymarin against thioacetamideinduced chronic liver fibrosis. Journal of the Science of Food and Agriculture 92 : 1441-7.

Churchill DN, Finn A, Gault M (1983) Association between hydrocharbon exposure and glomerulonephritis. Anaraisal of the evidence. Nephron Journal, 33: 169-172.

Curney ME, Cutting FB, Zhai P (1996) Benefit of vitamin E, riluzole and gabapentin in a transgenic model of familial amyotrophic lateral sclerosis. Annual Neurology 39: 147-157.

Dacie JV, Lewis MS (1993) In practical hematology 6th ed., ch 5, Churchill Livings ton, London and N.Y., Pp. 37.

Duncan DB (1955) Multiple range and multiple F. test. Biometrics 11,1.

El Miniawy HMF, Ahmed KA, Mansour S, Khattab MMS (2017) In vivo antitumour potential of camel's milk against hepatocellular carcinoma in rats and its improvement of cisplatin renal side effects. Pharmaceutical Biology 55:1513-1520.

El Miniawy HMF, Ahmed KA, Tony MA, Mansour S, Khattab MMS (2014) Camel milk inhibits murine hepatic carcinogenesis, initiated by diethylnitrosamine and promoted by phenobarbitone. International Journal of Veterinary Science and Medicine 2: 136141.

El-Agamy SI, Ruppanner R, Ismail A, Champagne CP, Assaf RJ (1992) Antibacterial and Antiviral activity of camel milk protective proteins. Journal of Dairy Research 59: 169-175.

Farah Z, Rettenmaier R, Atkins D (1992) "Vitamin content of camel milk". International journal for vitamin and nutrition research 62:30-33.
Fawcett JK, Scott JE (1960) A Rapid And Precise Method For The Determination Of Urea. Journal of Clinical Pathology 13: $156-159$.

Hai ZH, Bing W, Yong KL, Yong YB, Yan GU (2011) Hepatoprotective and Antioxidant Effects of Licorice Extract against CCL4-Induced Oxidative Damage in Rats. International Journal of Molecular Sciences 12: 6529-6543.

Hamed MA, Ali SA, El-Rigal NS (2012) Therapeutic Potential of Ginger against Renal Injury Induced by Carbon Tetrachloride in Rats. The Scientific World Journal : 1-12. doi: 10.1100/2012/840421.

Ibrahim MA, Wani FA, Rahiman S (2017) Hepatoprotective effect of olive oil and camel milk on acetaminophen-induced liver toxicity in mice. International Journal of Medical Science and Public Health 6: 186-194.

Jain NC (1986) Schalm's Veterinary Haematology 4th ed. Lea and Febiger, Philadelphia.

Khan MR, Rizvi W, Khan GN, Khan RA, Shaheen S (2009) Carbon tetrachloride-induced nephrotoxicity in rats: protective role of Digeramuricata. Journal of Ethnopharmacology 122 : 9199.

Khan MR, Afifa M, Shabbir M, Saeed N, Jasia B (2012) Antioxidant and hepatoprotective effects of oxalis corniculata against carbon tetrachloride ( $\mathrm{CCl} 4$.) induced injuries in rats. African Journal of Pharmacy and Pharmacology 6 : 2255-2267.

Kim SH, Yang YP, Sung SH, Kim CJ, Kim JW, Kim YC (2003) Hepatoprtective of dibenzylbuyrolactoneligans of Torreyanuciferaagainst CC14- induced toxicity in primary cultured rat hepatocytes. Biological and Pharmaceutical Bulletin $26: 1202-1205$.

Knockaert L, Berson A, Ribault C, Prost PE, Fautrel A, Pajaud J, Lepage S, Lucas-Clerc C, Bégué JM, Fromenty B, Robin MA (2012) Carbon tetrachloride-mediated lipid peroxidation induces early mitochondrial alterations in mouse liver. Laboratory Investigation 92: 396-410.

Knoess KH ( 1979) Milk Production of the Dromedary. In the Proceeding of the 1st (IFS ) International Symposium on Camels, (ISC'79), Sudan, Pp:201-202.

Korhonen H, Pihlanto A (2001) Bioactive peptides opportunities for designing future foods. Current Pharmaceutical Design 9: 1297-1308. 
Kraus A, Roth HP, Kirchgessner M (1997) Supplementation with vitamin $\mathrm{C}$, vitamin $\mathrm{E}$ or beta-carotene influences osmotic fragility and oxidative damage of erythrocytes of zinc-deficient rats. Journal of Nutrition $127: 1290-1296$.

Kumarappan CT, Vhand BS, Mandal SC, Sengottuvel T (2010) Hepatoprotective effect of the poly phenolic extract from ichnocarpus fruits scens leaves. Deccan Journal of Pharmacology $1: 1-16$.

Larsen K (1972) Creatinine assay by a reaction-kinetic principle. Clinica Chimica Acta 41:209-17.

Latif R, Lodhi GM, Aslam M (2008) Effects of amlodipine on serum testosterone, testicular weight and gonado-somatic index in adult rats," Journal of Ayub Medical College, Abbottabad 20: 810 .

Makni M, Yassine C, Hamadi F, El Mouldi G, Mohamed B, Chama M, Choumous K, Najiba Z (2012) Erythrocyte oxidative damage in rat treated with $\mathrm{CCl} 4$ protective role of vanillin. Saga Journal 28: 908-916.

Mandal A, Karmakar R, Bandyopadhyay S, Chatterjee M (1998) Antihepatotoxic potential of Trianthema portulacastrum in carbon tetrachloride-induced chronic hepatocellular injury biochemical characteristics. Archives of Pharmacal Research 21: 223-230.

Manibusan MK, Odin M, Eastmond DA (2007) Postulated carbon tetrachloride mode of action: A review. Journal of Environmental Science and Health 25: 185-209.

Maxine M, Benjamin BS (1985) Outline of veterinary clinical pathology (3rdEdn) Rakha printers PVT. LTD. New Delhi.

Mayuren C, Reddy VV, Priya SV, Devi VA (2010) Protective effect of Livactine against $\mathrm{CCl} 4$ and paracetamol induced hepatotoxicity in adult Wistar rats. North American Journal of Medical Sciences 2:491- 495.

McDowell L (2000) Vitamins in Animal and Human Nutrition .2nd ed. Iowa State Univ. Press. Iowa, USA., Pp: 155-225.

Nishikimi M, Roa NA, Yogi K (1972) The occurrence of superoxide 728 anion in the reaction of reduced phenazinemetho sulfate and molecular oxygen. Biochemical and Biophysical Research Communications, 46: 849-854.

Omar TY, Hmmam FH (2014) Effect of Camel Milk on Hepatic Antioxidant Enzymes in Rabbits Intoxicated with Carbon Tetrachloride. International Journal of Biological \& Pharmaceutical Research 5: 461-468.
Ozturk F, Ucar M, Ozturk IC, Vardi N, Batcioglu K(2003) Carbon tetrachloride-induced nephrotoxicity and protective effect of betaine in Sprage-Dawley rats. Urology 62:353-356.

Parveen R, Baboota S, Ali J, Ahuja A, Vasudev SS, Ahmad S (2011) Effects of silymarinnano emulsion against carbon tetrachloride-induced hepatic damage. Archives of Pharmacal Research 34:767-774.

Perez AJ, Courel M, Sobrado J, Gonzalez L (1987) Acute renal failure after topical application of carbon tetrachloride. Lancet 1 : 515-516.

Rao MB, Gupta RC, Dastur NN (1970) Camels' milk and milk products. Indian Journal of Dairy Science 23: 71-78.

Sahreen S, Khan MR, Khan RA (2013) Ameliorating Effect of Various Fractions of Rumex hastatus Roots against Hepato- and Testicular Toxicity Caused by CCl4. Oxidative Medicine and Cellular Longevity 2013:1-11. http://dx.doi.org/10.1155/2013/325406.

Satoh K (1978) Serum lipid peroxide in cerebrovascular disorders determined by a new colorimetric method. Clinica Chimica Acta 90:37-43.

Shaker ME, Zalata KR, Mehal WZ, Shiha GE, Ibrahim TM (2011) Comparison of imatinib, nilotinib and silymarin in the treatment of carbon tetrachloride-induced hepatic oxidative stress, injury and fibrosis. Toxicology and Applied Pharmacology 252:165-175.

Singh N, Kamath V, Narasimhamurthy K, Rajini PS (2008) Protective effect of potato peel extract against carbon tetrachlorideinduced liver injury in rats. Environmental Toxicology and Pharmacology 26 : 241-246. doi: 10.1016/j.etap.2008.05.006.

Snedecor GW, Cochran WG (1982) statistical methods. 7th ed., the lawa state university Press, Ames, Lawa, USA, Pp.215.

Soliman MM, Attia HF, Nassan MA (2016) Protective effect of camel milk on genetic and histopathological changes retated to fertility and vision in diabetic wistar rats. lucrăriștiinţifice vol. 59 medicinăveterinarăpartea $1: 33-54$.

Swenson MJ (1993) Physiological properties and cellular and chemical constituent of blood. In: Dukes' Physiology of domestic animals. Comstock Publishing Associates, Ithaca and London Pp. 29-32.

Tung HT, Cook FW, Wyatt RD, Hamilton PB (1975) The anemia caused by aflatoxin. Poultry science 54: 1962-1969. 
US EPA IRIS (2010) Toxicological review of carbon tetrachloride (External Review Draft). U.S. Environmental Protection Agency, Washington, DC, EPA/635/R-08/005A. Available at www.epa.gov/iris/toxreviews/0020tr.pdf accessed on 25th September 2012.

Vargas-Mendoza N, Madrigal-Santillán E, Morales-González A, Esquivel-Soto J, Esquivel-Chirino C, García-Luna Y, GonzálezRubio M (2014) Hepatoprotective effect of silymarin. World Journal of Hepatology $6: 144-149$.

Veldink JH, Kalmijn S, Groeneveld GJ, Wunderink W, Koster A, de Vries JHM, Van der Luyt J, Wokke JHJ, Van den Berg LH (2007) Intake of polyunsaturated fatty acids and vitamin E reduces the risk of developing amyotrophic lateral sclerosis. Journal of Neurology, Neurosurgery and Psychiatry 78: 367 371.

Venkatanarayana G, Sudhakara G, Sivajyothi P, Indira P (2012) Protective effects of curcumin and vitamin E on carbon tetrachloride-induced nephrotoxicity in rats. EXCU Journal 11: 641-650.

Videla LA, Valenzuela A (1982) Alcohol ingestion, liver glutathione and lipoperoxidation: metabolic interrelations and pathological implications. Life Sciences - Journal 31: 2395-2407.

Yacout GA, Elguindy NM, EI Azab EF (2012) Hepatoprotective effect of basil (Ocimum basilicum L.) on CCI.-induced liver fibrosis in rats. African Journal of Biotechnology 11: 1570215711.

Yagil R, Saran A, Etzion Z (1984) Camel's milk: for drinking only? Comparative Biochemistry and Physiology - Part A: Molecular \& Integrative Physiology 78: 263-266.

Yang BY, Zhang XY, Guan SW, Hua ZC (2015) Protective effect of procyanidin $\mathrm{B} 2$ against $\mathrm{CCl} 4$-induced acute liver injury in mice. Molecules 20: 12250-12265.

Young DS, Thomas DW, Friedman RB, Pestaner LC (1972) Effects of drugs on clinical laboratory tests. Clinical Chemistry 18:1041- 1303.

Yousef MI, Awad TI, Mohamed EH (2006) Deltamethrin induced oxidative Damage and biochemical alterations in rat and its attenuation by Vitamin E. Toxicology 29: 240 - 247.

Youssef WI, Mullen KD (2002) The liver in other (nondiabetic) endocrine disorders. Clinical Liver Disease 6: 879-89.

Zietz B, Lock G, Plach B, Drobnik W, Grossmann J, Schölmerich J, Straub RH (2003) Dysfunction of the hypothalamic- pituitaryglandular axes and relation to Child-Pughclassification in male patients with alcoholic and virus-relatedcirrhosis. European Journal of Gastroenterology \& Hepatology. 15: 495-01. 